\title{
Perangkat Visualisasi Metamorfosis Kupu-kupu Menggunakan Animated Augmented Reality
}

\section{Butterfly Metamorphosis Visualization Learning Tool Using Animated Augmented Reality}

\author{
Andria Kusuma Wahyudi, Freandy Fernando Mewo, Sabatino Ganda \\ ${ }^{123}$ Fakultas Ilmu Komputer, Jurusan Teknik Informatika, Universitas Klabat \\ *11andriawahyudi@unklab.ac.id, ${ }^{2} 11310056 @$ student.unklab.ac.id, \\ 311310642@student.unklab.ac.id
}

\begin{abstract}
Abstrak
Aplikasi ini menampilkan visualisasi metamorfosis kupu-kupu dan jenis jenis kupu kupu. Pada saat ini media visualisasi metamorfosis kupu-kupu masih terbatas pada tampilan $2 D$ dan belum bisa di lihat secara keseluruhan. Umumnya media pengenalan metamorfosis kupu-kupu masih menggunakan buku ataupun poster yang terbatas 2D saja dan ukurannya tidak sama persis seprti ukuran aslinya. Aplikasi ini merupakan aplikasi augmented reality pada smartphone yang dapat menampilkan proses metamorfosis kupu-kupu dan jenis-jenis kupu-kupu dengan menampilkan gambar 3D dari setiap objek metamorfosis dan jenis-jenis kupu-kupu secara detail dan dengan skala yang sesunguhnya. Paper ini membahas cara pembuatan, pengumpulan data, perancangan aplikasi dan implementasi. Hasilnya adalah aplikasi visual 3D disempurnakan dengan animasi, text, narrator, yang dapat menstimulasi lebih dari satu indra dan model game kuis yang dapat di jalankan dalam smartphone berbasis android.
\end{abstract}

Kata kunci-Augmented Reality, Metamorfosis Kupu-kupu, interaktif media, Animasi.

\section{Abstract}

This app displays the visualization of butterfly metamorphosis and the type of butterfly species. Nowdays the media visualization of butterfly metamorphosis is still limited to $2 D$ display and can not be viewed as a whole. Generally, the medium of introduction of butterfly metamorphosis still uses books or posters that are limited to $2 D$ only and the size is not exactly the same as the original size. This application is an augmented reality application on a smartphone that can display the process of butterfly metamorphosis and the types of butterflies by displaying $3 D$ images of each object metamorphosis and butterfly species in detail and with the true scale. This paper discusses the way of making, data collection, application design and implementation. The result is a $3 D$ visual application with a enhanced by animation, text, narrator, which can stimulate more than one senses and game quiz models that can run on an android-based smartphone.

Keywords - Augmented Reality, Butterfly Metamorphose, Interactive Media, Animation.

\section{PENDAHULUAN}

Metamorfosis adalah suatu proses perkembangan biologi pada hewan yang melibatkan perubahan penampilan dan/atau struktur setelah kelahiran atau penetasan. Perubahan fisik itu terjadi akibat pertumbuhan sel dan differensiasi sel atau proses yang terlihat dalam organisme multisel yang secara radikal berbeda[1]. Metamorfosis kupu-kupu sempurna yaitu metamorfosis yang mempunyai empat tahap pertumbuhan. Tahapan tersebut yaitu, telur, larva, pupa dan 
dewasa. Metamorfosis kupu-kupu tidak sempurna yaitu metamorfosis yang hanya mempunyai 3 tahap pertumbuhan yaitu telur, nimfa dan dewasa[2]. Pengenalan metamorfosis kupu-kupu pada umumnya diajarkan pada anak SMP.

Media pengenalan metamorfisis kupu-kupu pada anak SMP sekarang menggunakan video, buku, dan gambar dari sudut pandang anatomi kupu-kupu masih masih terbatas dua dimensi. Karena saat ini, media pengenalan hanya menggunakan buku ataupun poster yang hanya berupa gambar (2D) saja dan ukuran yang ditampilkan kurang persis dengan ukuran aslinya. Metode pengenalan metamorfosis kupu-kupu dapat diterapkan dalam bentuk Augmented Reality yang dapat merealisasikan dunia virtual ke dunia nyata, sehingga dapat mengubah objek-objek tersebut (metamorfosis kupu-kupu) menjadi objek 3D.

Saat ini Augmented Reality menjadi sumber dari cara komunikasi pembelajaran baru karena dapat mengkombinasikan teks, gambar, video yang tidak bisa di dapatkan dari buku.[3] Augmented Reality adalah teknologi yang menggabungkan benda dua dimensi dan ataupun tiga dimensi ke dalam sebuah lingkungan nyata tiga dimensi lalu memproyeksikan benda benda tersebut dalam waktu nyata [4]. AR menjadi cara komunikasi konten yang baru, sebagai kombinasi teks, 3D model, video, yang memberikan perspektif baru [5][6]. Penelitian terbaru menemukan bahwa penggunaan 3D digital objek yang di aplikasikan ke lingkungan fisik dapat menghasilkan pengalaman yang signifikan[7][8]. Dalam survey yang di lakukan saat ini teknologi Augmented Reality sangat sesuai untuk di implementasi dalam pembelajaran [9].

Penelitian ini akan menggunakan teknologi Augmented Reality untuk menampilkan metamorphosis kupu kupu untuk digunakan pada siswa SMP. Diharapkan dengan menerapkan teknologi AR dapat memberikan perspektif baru dan pengalaman yang signifikan dalam belajar. Adapun di lengkapi dengan amimasi gerakan untuk menambah meningkatkan persepsi dari pengguna.

\section{METODE PENELITIAN}

Metode penelitian yang akan digunakan adalah Rekayasa Perangkat Lunak (RPL). Dimana RPL adalah sebuah teknik kedisiplinan dalam merekayasa yang berkaitan dengan semua aspek pembuatan perangkat lunak mulai dari tahap awal pembuatan sistem sampai menjaga sistem setelah sistem yang dibuat mulai digunakan. Penelitian ini menggunakan Rekayasa Perangkat Lunak karena dapat meningkatkan kualitas dari perangkat lunak.

Peneliti menggunakan teknik observasi dokumen, study literature dan wawancara untuk mengumpulkan data. Metode observasi dilakukan dengan mencari penelitian-penelitian terhadap aplikasi Augmented Reality dan sistem pengenalan yang ada sebelumnya yang bertujuan untuk mempelajari cara kerja dari sistem sebelumnya agar dapat membantu dalam proses pembuatan aplikasi selanjutnya. Study literature dilakukan dengan cara mencari informasi sebanyak mungkin melalui buku dan e-book yang relevan sesuai dengan tujuan penelitian. Wawancara dilakukan untuk mencari informasi tentang metode pembelajaran metamorfosis kupu-kupu.

Dalam intstrumen pengumpulan data peneliti mengumpulkan kutipan-kutipan dalam buku dan karyah ilmiah yang tersedia di perpustakaan, buku yang dibeli secara pribadi dan website yang menyediakan tulisan-tulisan yang relevan sehinggan dapat mendukung penelitian. Dalam kebutuhan pengembangan aplikasi, peneliti membuat gambar 3D. Hasil pembuatan gambar 3D bertujuan untuk memberi referensi pada pemodelan aplikasi ini.

\section{HASIL DAN PEMBAHASAN}

Aplikasi yang akan dikembangkan menggunakan Use Case Diagram untuk mendapatkan gambaran umum tentang fungsionalitas dari aplikasi yang akan dibangun khususnya interaksi antara pengguna dengan aplikasi. 


\subsection{Use Case Diagram}

Use Case Diagram digunakan untuk menggambarkan apa yang dilakukan oleh aplikasi dan mempresentasikan interaksi antara actor dan aplikasi. Dalam penelitian ini, pengguna menjadi actor utama yang berinteraksi dengan aplikasi. Untuk lebih jelas Use Case Diagram dari aplikasi pengenalan Metamorfosis Kupu-kupu menggunakan teknologi Augmented Rality berbasis Android ini dapat dilihat pada Gambar 1.

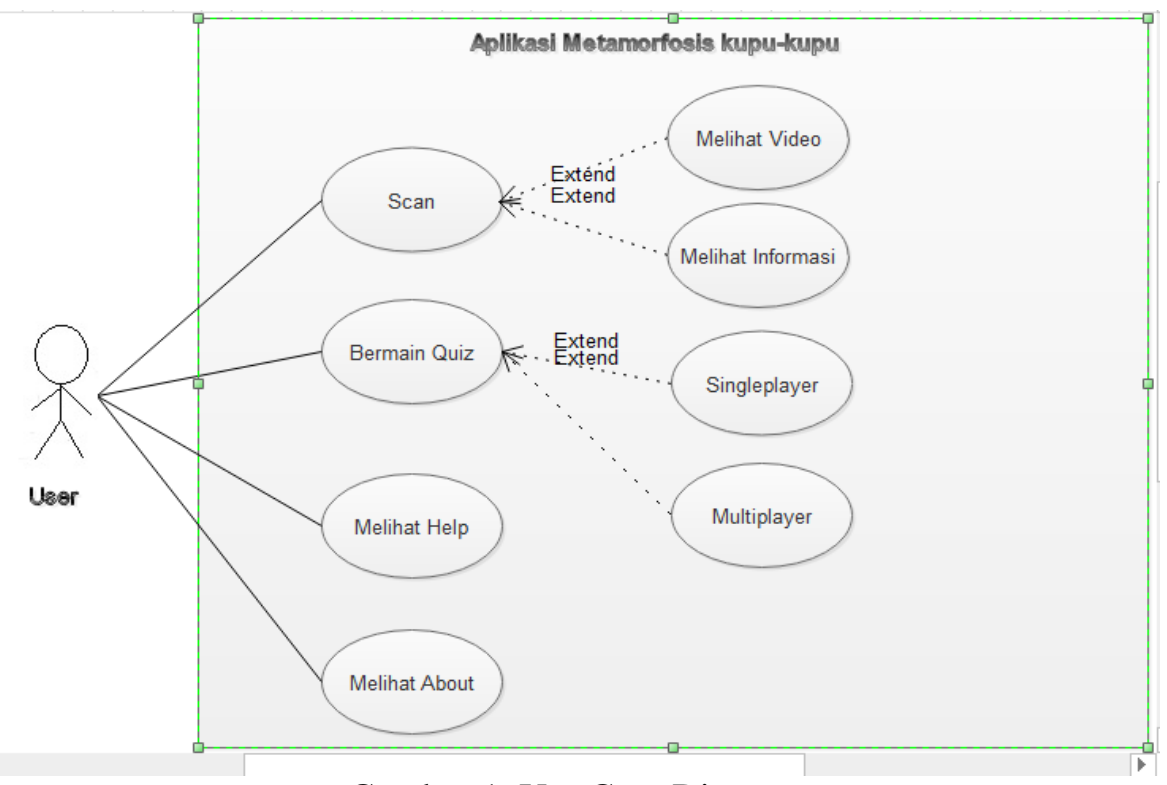

Gambar 1. Use Case Diagram

Pada gambar 2.1 menjelaskan tentang use case dari aplikasi Metamorfosis Kupu-kupu dimana user dapat melakukan Scan, yaitu user dapat melihat video metamofosis kupu-kupu dan dapat melihat informasi dari setiap tahap metamorfosis kupu-kupu serta jenis-jenis dari kupukupu. Juga user dapat Bermain Quiz, yaitu user dapat bermain game tentang metamorfosis kupu-kupu dimana user dapat bermain singleplayer ataupun multiplayer. User juga dapat melihat help, yaitu informasi tentang cara menggunakan aplikasi. Serta user juga dapat melihat About, dimana user dapat melihat informasi dari developer application.

\subsection{Activity Diagram}

Pada activity diagram, menggambarkan alur aktivitas dalam system yang sedang dirancang, bagaimana masing-masing alur aktivitas berawal, decision yang mungkin terjadi, dan bagaimana alur dari aktivitas tersebut berakhir. 
Activity Diagram Melihat Scan

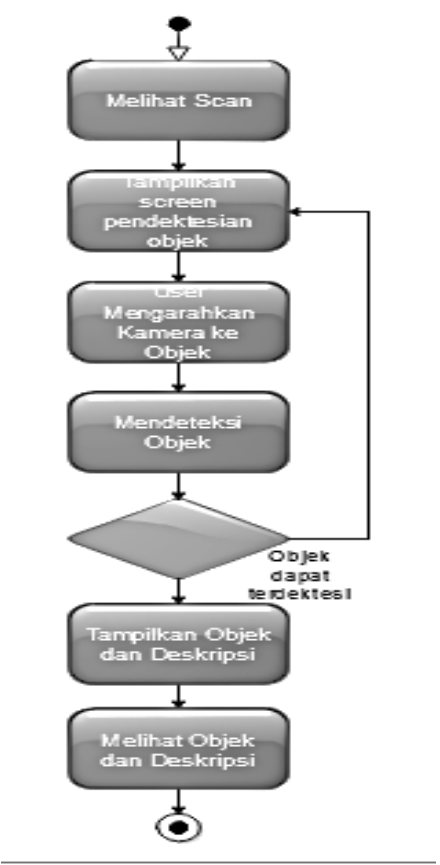

Gambar 2. Activity Diagram Melihat Scan

Gambar 2 menjelaskan tentang activity diagram Melihat Scan.Alur kerja yang terjadi pada Melihat Scan sebagai berikut.

1. User masuk ke Melihat Scan.

2. Aplikasi menampilkan screen pendektesi image target.

3. Selanjutnya user mengarahkan kamera ke objek atau image target yang diberikan apakah sesuai atau tidak.

4. Jika sesuai, maka aplikasi akan me-render dan menampilkan gambar 3D metamorfosis kupu-kupu beserta informasinya, galery kupu-kupu beserta informasinya dan video yang ada. Dan jika tidak sesuai maka aplikasi akan tetap berada pada screen pendeteksi image target.

Activity Diagram Bermain Quiz

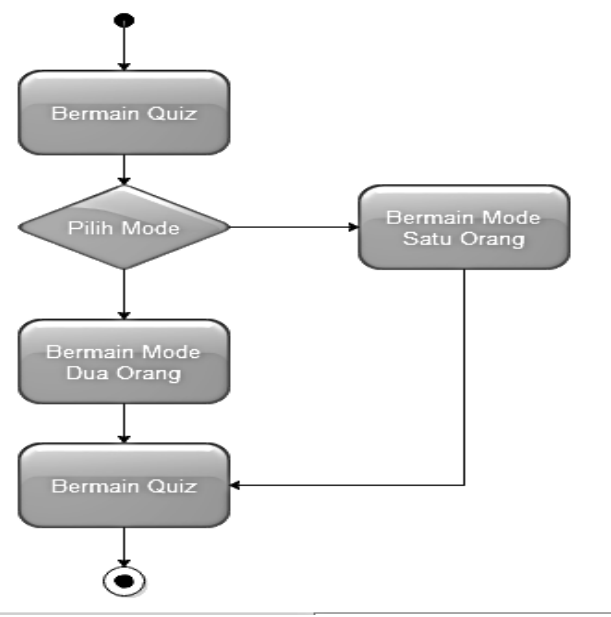


Gambar 3. Activity Diagram Bermain Quiz

Pada gambar 3 menjelaskan tentang analisa Activity Diagram Bermain Quiz, dengan penjelasan sebagai berikut:

1. User masuk ke Bermain Quiz

2. Aplikasi menampilkan pilihan mode permainan

3. Jika mode yang dipiih untuk satu orang maka, aplikasi akan menampilkan pertanyaan dengan mode satu orang saja

4. Jika mode yang dipilih untuk dua orang maka, aplikasi akan menampilkan pertanyaan dengan mode dua orang

Activity Diagram Melihat Help

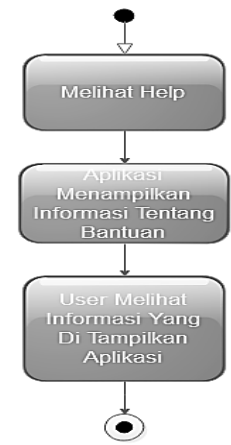

Gambar 4. melihat Help

Gambar 4 menjelaskan tentang activity diagram Melihat Help. Alur kerja yang terjadi pada Melihat Help sebagai berikut.

1. User masuk atau menekan tombol Melihat Help

2. Kemudian system akan menampilkan informasi tentang bantuan atau panduan tentang cara menggunakan aplikasi.

3. User kemudian dapat melihat informasi tentang bantuan cara menggunakan aplikasi yang ditampilkan aplikasi.

\subsection{Class Diagram}

Class Diagram memberikan gambaran dari setiap class yang terdapat dalam aplikasi pengenalan metamorfosis kupu-kupu menggunakan teknologi Augmented Reality berbasis Android. Berikut ini adalah gambar class diagram yang dapat dilihat pada Gambar 5.

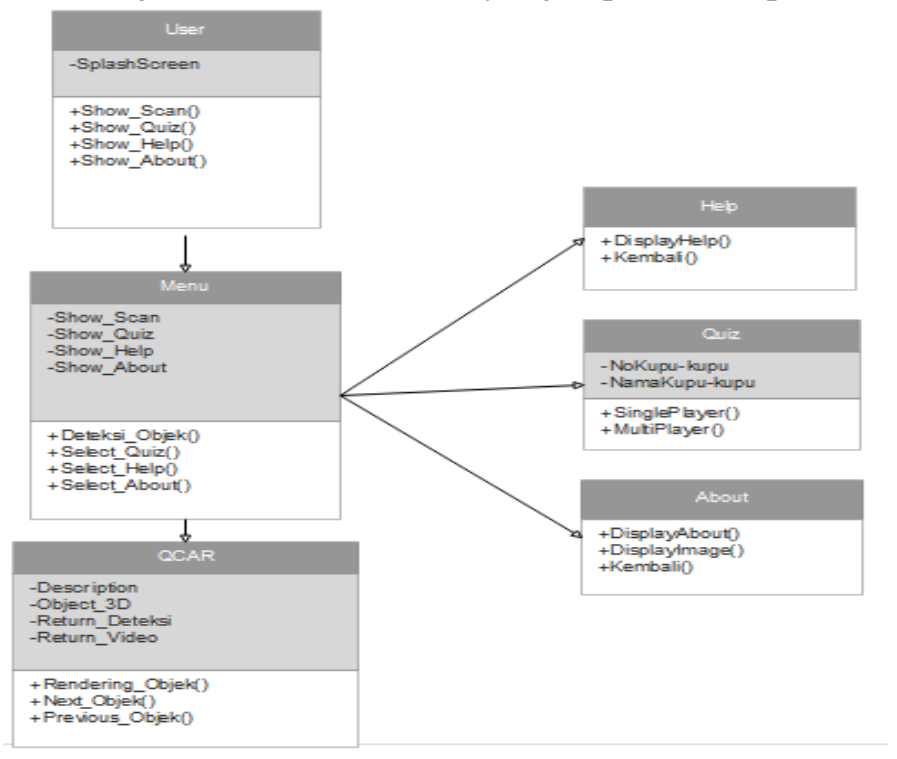

Gambar 5. Class Diagram 
Gambar 5 menggambarkan class diagram dari hasil analisa yang berisi atribut dan operasi dari setiap class. Penjelasannya sebagai berikut:

a. Class User, melihat menu aplikasi.

b. Class Menu, menampilkan menu yang berisi pilihan yang dapat dipilih oleh user pada aplikasi.

c. Class $Q C A R$, menampilkan kamera yang nantinya akan me-render image target dan akan menampilkan gambar 3D dan penjelasan berupa teks serta video sesuai dengan image target yang di-render.

d. Class Help, menampilkan informasi dari cara penggunaan aplikasi berupa penjelasan dalam bentuk teks.

e. Class Quiz, menampilkan soal quiz tentang metamorfosis kupu-kupu dan jenis-jenis kupu-kupu.

f. Class About, menampilkan informasi dari pembuat aplikasi.

\subsection{Sequence Diagram}

Sequence diagram digunakan oleh peneliti untuk menggambarkan interaksi antar objek yang ada dan jalur-jalur proses yang terjadi di dalam aplikasi, sequence diagram menunju+kan bagaimana proses kerja antar satu dengan yang lain berdasarkan urutanya. Sequence diagram menggambarkan interaksi antar objek di dalam dan di sekitar sistem atau aplikasi.

Sequence Diagram Lihat Scan

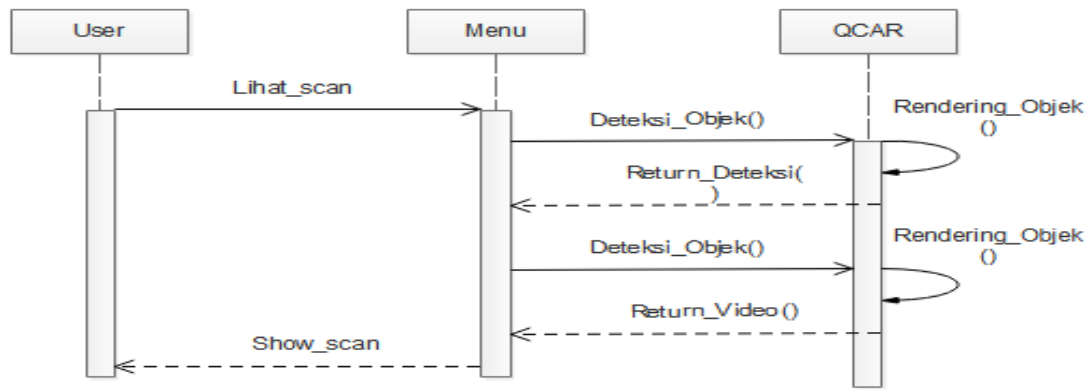

Gambar 6 Sequence Diagram Lihat Scan

Sequence Diagram pada gambar 6 menggambarkan pengguna aplikasi apabila user dapat melihat scan dari hasil pendeteksian sebelumnya. Jika sebelumnya objek terdeteksi, maka aplikasi akan me-render dan mengembalikan output dalam bentuk gambar 3D jenis-jenis kupukupu dan 3D metamorfosis kupu-kupu beserta penjelasannya dalam bentuk teks dam video. Jikat tidak, maka aplikasi akan menampilkan tampilan pendeteksi.

Sequence Diagram Bermain Quiz

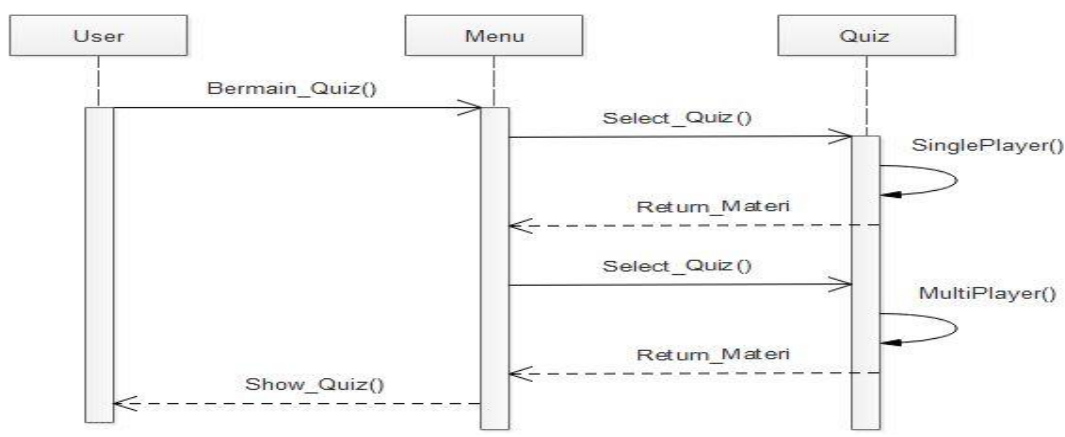


Gambar 7 Sequence Diagram Bermain Quiz

Sequence Diagram pada gambar 7. saat user memilih play quiz maka aplikasi akan menampilkan pilihan mode single player dan multiplayer. Kemudian aplikasi akan menampilkan soal quiz sesuai dengan mode permainan yang dipilih oleh user.

\section{Sequence Diagram Melihat Help}

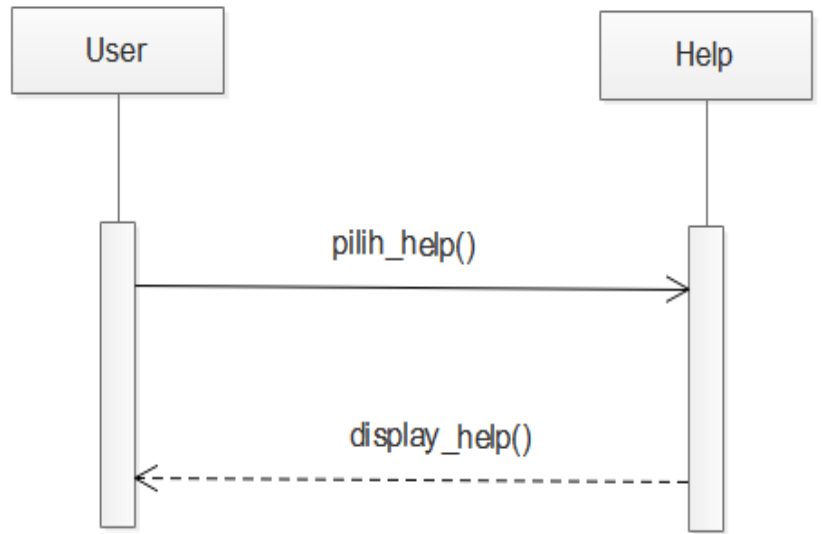

Gambar 7. Sequence Diagram Melihat Help

Sequence help pada gambar 7 menjelaskan tantang apabila user memilih Help, maka aplikasi akan menampilkan panduan panggunaan dari aplikasi.

\section{Sequence Diagram Melihat About}

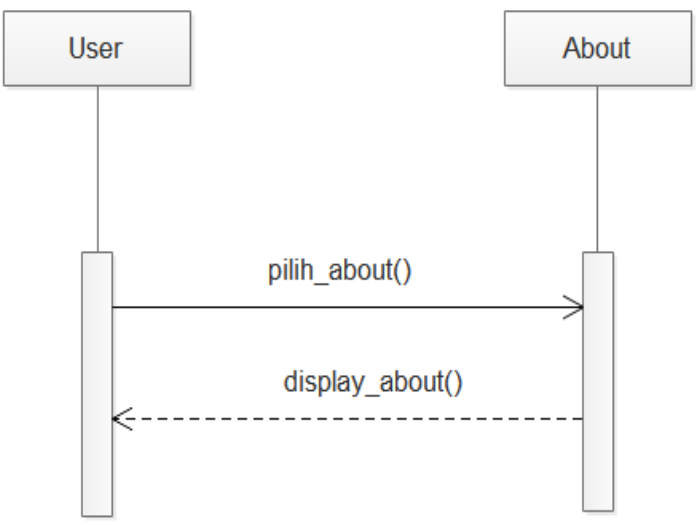

Gambar 8. Sequence Diagram Melihat About

Sequence about pada gambar 8 menjelaskan tentang user memilih About, maka aplikasi akan menampilkan tentang informasi dalam bentuk teks dan gambar dari developer dari aplikasi.

\subsection{Implementasi}

Berikut adalah implementasi dari pembuatan Aplikasi Metamorfosis kupu-kupu, diantaranya implementasi dataset, modeling, dan implementasi antarmuka, sebagai berikut: 


\section{A. Dataset}

Tabel ini merupakan implementasi dari dataset yang digunakan dalam aplikasi ini. Terdapat dua tabel dalam dataset aplikasi ini. Yang pertama tabel image target yang menampilkan Metamorfosis Kupu-kupu dan tabel image target yang menampilkan Jenis-jenis Kupu-kupu.

Tabel 1. Image Target Metamorfosis Kupu-kupu

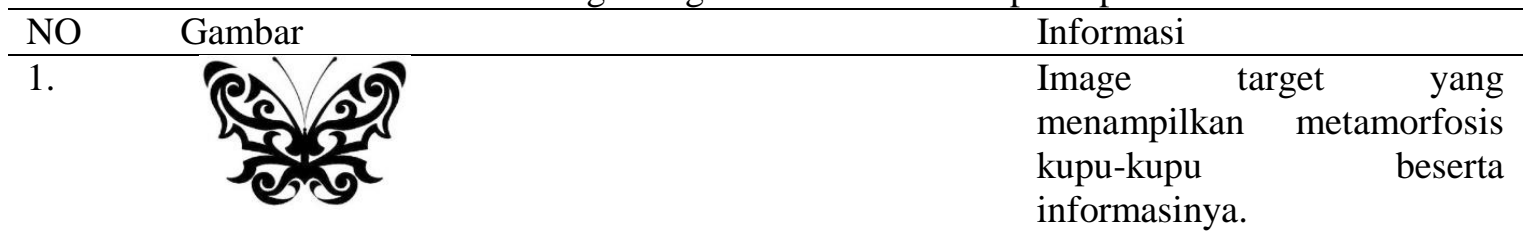

Pada tabel 1 adalah image target dari metamorfosis kupu-kupu

Tabel 2. Image Target Jenis-jenis Kupu-kupu

\begin{tabular}{lll}
\hline NO Gambar & Informasi \\
\hline 1. & $\begin{array}{l}\text { Image target yang } \\
\text { menampilkan Jenis-jenis } \\
\text { kupu-kupu } \\
\text { informasinya. }\end{array}$
\end{tabular}

Pada tabel 2. adalah image target dari jenis-jenis kupu-kupu.

\section{B. 3D Model dan Rerources}

Model 3D yang digunakan adalah 3D model yang di rancang menggunakan Blender 3D dan menggunakan asset yang di beli dari situs penyedia jasa 3D model.

Tabel 3. Menampilkan resources

\begin{tabular}{|c|c|c|c|c|c|}
\hline No. & Antarmuka & Marker & Audio & Images & 3D Model \\
\hline 1 & Menu & - & $\begin{array}{l}\text { Welcome_sound.mp3 } \\
\text { Button_click.mp3 } \\
\text { Button_close.mp3 }\end{array}$ & $\begin{array}{l}\text { Background.jpg } \\
\text { LogoIcon.jpg } \\
\text { Button.jpg } \\
\end{array}$ & - \\
\hline 2 & Scan Metamorfosis & & $\begin{array}{l}\text { Button_click.mp3 } \\
\text { Button_close.mp3 } \\
\text { NaratorFase1.mp3 } \\
\text { NaratorFase2.mp3 } \\
\text { NaratorFase3.mp3 } \\
\text { NaratorFase4.mp3 } \\
\text { NaratorFase5.mp3 } \\
\text { NaratorFase6.mp3 }\end{array}$ & $\begin{array}{l}\text { Background.jpg } \\
\text { LogoIcon.jpg } \\
\text { Button.jpg }\end{array}$ & $\begin{array}{l}\text { Fase1.obj } \\
\text { Fase1.mtl } \\
\text { Fase2.obj } \\
\text { Fase2.mtl } \\
\text { Fase3.obj } \\
\text { Fase3.mtl } \\
\text { Fase4.obj } \\
\text { Fase4.mtl -7 }\end{array}$ \\
\hline 3 & Jenis Kupu Kupu & & $\begin{array}{l}\text { Button_click.mp3 } \\
\text { Button_close.mp3 } \\
\text { Narator_info1.mp3 } \\
\text { Narator_info2 mp3 } \\
\text { Narator_info3 mp3 } \\
\text { Narator_info4 mp3 } \\
\text { Narator_info5 mp3 }\end{array}$ & $\begin{array}{l}\text { Background.jpg } \\
\text { LogoIcon.jpg } \\
\text { Button.jpg }\end{array}$ & $\begin{array}{l}\text { Tipe1.obj } \\
\text { Tipe2.obj } \\
\text { Tipe3.obj } \\
\text { Tipe4.obj } \\
\text { Tipe5.obj } \\
\text { Tipe6.obj } \\
\text { Tipe7.obj }\end{array}$ \\
\hline 4 & Detail Kupu Kupu & 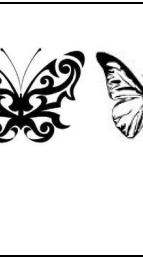 & $\begin{array}{l}\text { Button_click.mp3 } \\
\text { Button_close.mp3 }\end{array}$ & $\begin{array}{l}\text { Background.jpg } \\
\text { LogoIcon.jpg } \\
\text { Button.jpg }\end{array}$ & $\begin{array}{l}\text { Tipe1.obj } \\
\text { Tipe2.obj } \\
\text { Tipe3.obj } \\
\text { Tipe4.obj } \\
\text { Tipe5.obj } \\
\text { Tipe6.obj } \\
\text { Tipe7.obj }\end{array}$ \\
\hline
\end{tabular}


Andria Kusuma Wahyudi, Freandy Fernando Mewo, Sabatino Ganda

\begin{tabular}{|c|c|c|c|c|c|}
\hline 5 & Quiz & - & $\begin{array}{l}\text { Button_click.mp3 } \\
\text { Button_close.mp3 }\end{array}$ & $\begin{array}{l}\text { Background.jpg } \\
\text { LogoIcon.jpg } \\
\text { Button.jpg }\end{array}$ & - \\
\hline 6 & About & - & $\begin{array}{l}\text { Button_click.mp3 } \\
\text { Button_close.mp3 }\end{array}$ & $\begin{array}{l}\text { Background.jpg } \\
\text { LogoIcon.jpg } \\
\text { Button.jpg }\end{array}$ & - \\
\hline 7 & Helo & - & $\begin{array}{l}\text { Button_click.mp3 } \\
\text { Button_close.mp3 }\end{array}$ & $\begin{array}{l}\text { Background.jpg } \\
\text { LogoIcon.jpg } \\
\text { Button.jpg }\end{array}$ & - \\
\hline
\end{tabular}

\section{Antarmuka}

Berikut ini merupakan tampilan antarmuka dari aplikasi Pengenalan Metamorfosis Kupu-kupu Menggunakan Augmented Reality.

Tampilan Antarmuka Menu

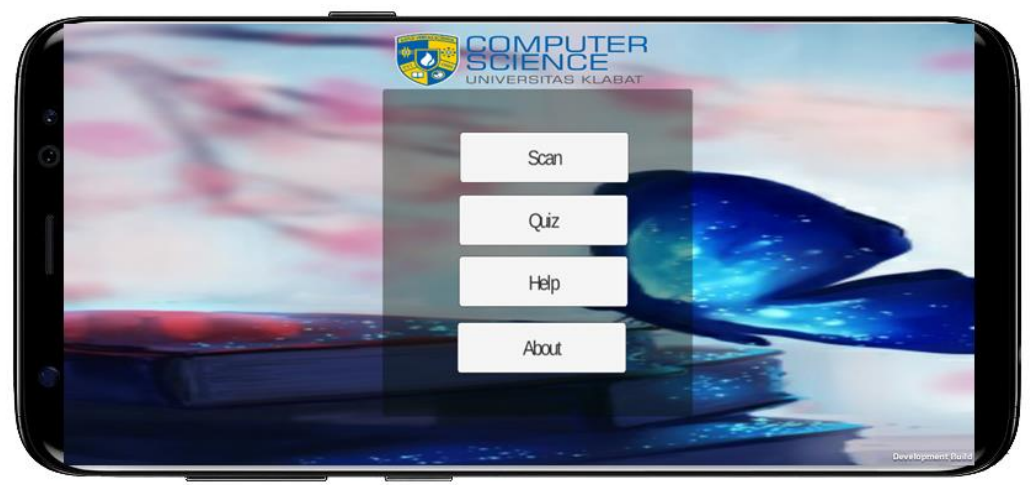

Gambar 9.Tampilan Antarmuka Menu

Pada gambar 9 menampilkan tampilan antarmuka menu pada aplikasi yang dibuat. Dimana didalam menu ada fungsi yang dapat dilakukan oleh user, yaitu Scan, Quiz, Help dan About. Dalam Scan ada scan metamorfosis kupu-kupu dan scan jenis-jenis kupu-kupu berserta informasinya.

Tampilan Antarmuka Scan Metamorfosis

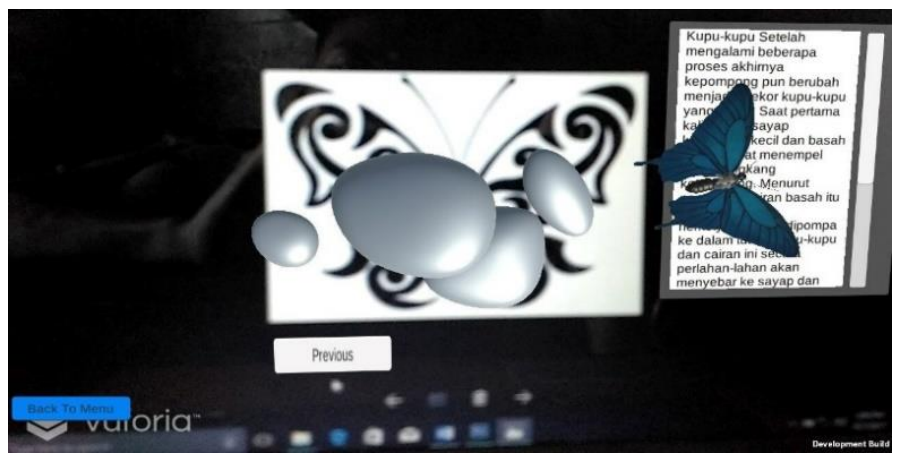

Gambar 10. Tampilan Antarmuka Scan Metamorfosis Kupu-kupu

Pada gambar 10 adalah tampilan antarmuka scan metamorfosis kupu-kupu beserta informasinya. Untuk melihat setiap fase, pengguna dapat menekan tombol proses, dan otomatis aplikasi akan menampilakn tampilan 3D kupu kupu setiap fase. Untuk melihat fase yang lain pengguna dapat menekan tombol next. 


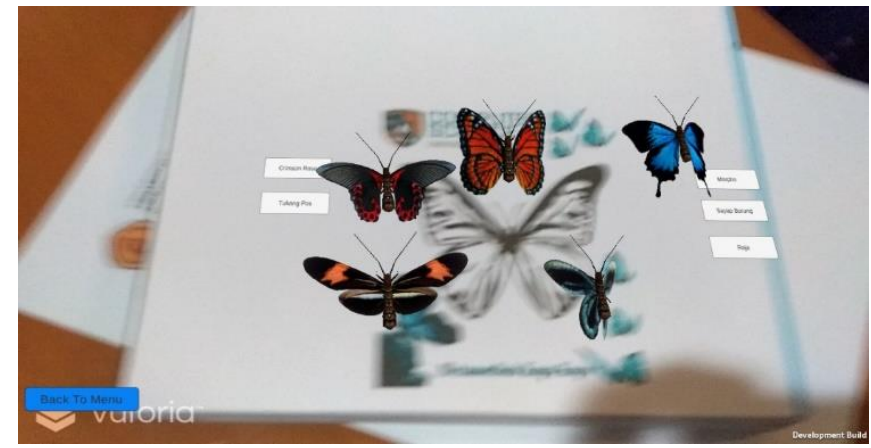

Gambar 11. Tampilan Antarmuka Scan Jenis-jenis Kupu-kupu

Pada gambar 11 adalah tampilan antarmuka scan dari jenis-jenis kupu-kupu. Dalam tampilan ini, akan di tampilkan semua kupu kupu yang ada. Untuk melihat informasi dari setiap kupu kupu pengguna dapat menkan tombol pada layar atau menekan objek kupu kupu.

\section{Tampilan Antarmuka Detail informasi}

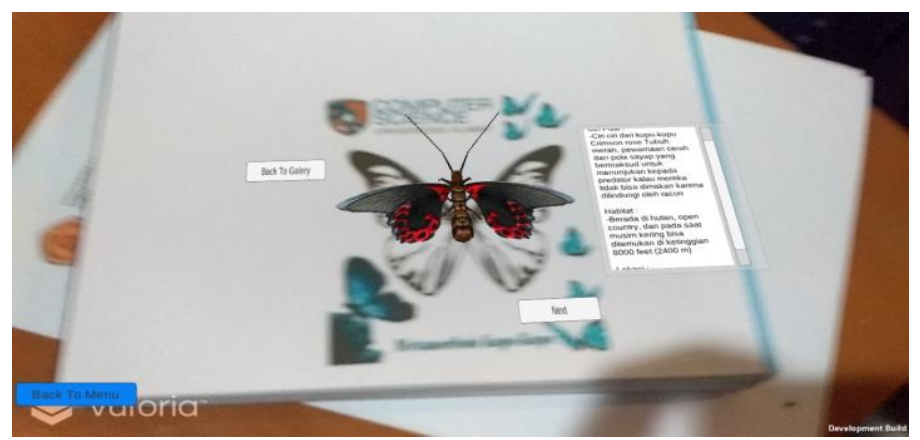

Gambar 12. Tampilan Antarmuka Scan Informasi Jenis Kupu-kupu

Pada gambar 12 adalah tampilan antarmuka dari scan informasi jenis-jenis kupu-kupu beserta gambarnya. Informasi yang ditampilkan adalah informasi umum yang didapatkan dalam buku IPA SMP.

Tampilan Antarmuka Quiz

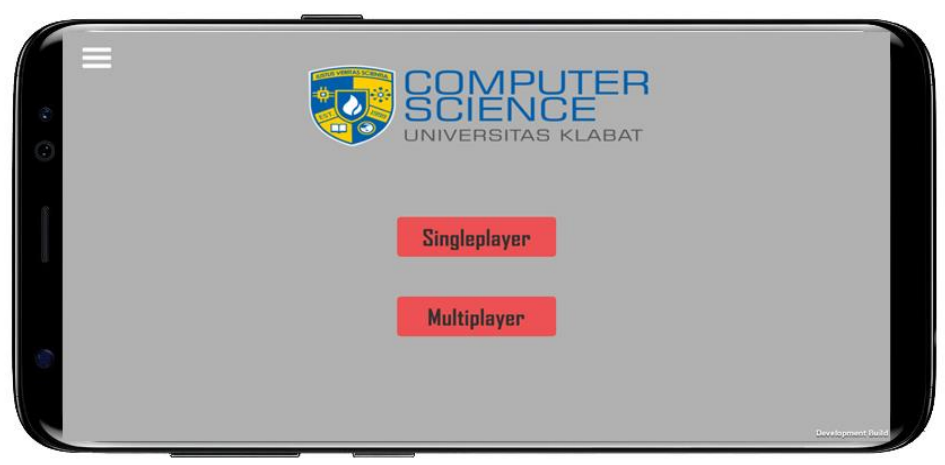

Gambar 13. Tampilan Antarmuka Quiz 
Pada gambar 13 adalah tampilan antarmuka dari quiz. Dimana quiz dapat dimaikan satu orang saat menekan tombol play dan dua orang saat menekan tombol multiplayer. Jika menekan single player aplikasi akan menampilakn soal pertanyaan dan mendapatkan score jika benar. Untuk multiplayer aplikasi akan menyanyakan 2 kali pertanyaan dan dapat di jawab oleh masing masing pengguna.

\section{Tampilan Antarmuka About}

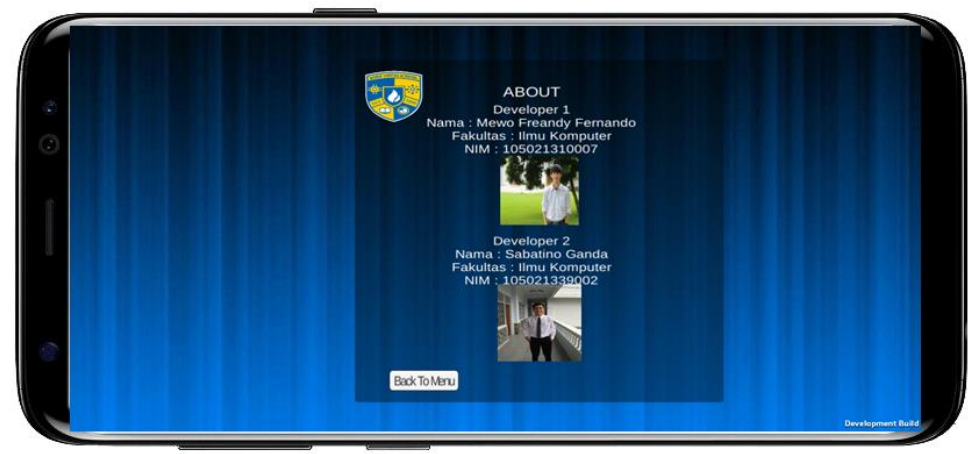

Gambar 14. Tampilan Antarmuka About

Pada gambar 14 adalah tampilan antarmuka about yang menampilkan tentang informasi dari developer.

\section{Tampilan Antarmuka Help}

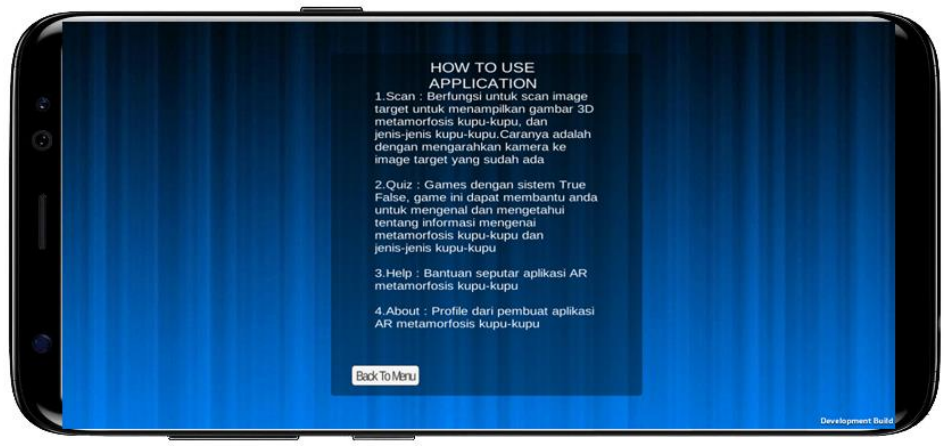

Gambar 15. Tampilan Antarmuka Help

Pada gambar 2.8 adalah tampilan antarmuka dari help yang menampilkan cara pemakaian dari aplikasi Metamorfosis kupu-kupu.

\section{KESIMPULAN}

Paper ini menampilkan perancangan aplikasi visualisasi metamorphosis kupu kupu mengunakan Augmented Reality. Aplikasi ini dapat di operasikan menggunakan system operasi Android. Aplikasi ini menambah cara dan metode dalam melihat objek kupu kupu secara 3D. Dalam implementasi dengan menggunakan Augmented Reality objek 3D seperti kupu kupu, kepompong, dan semua bentuk kupu kupu dapat di lihat dari segala arah. Dengan kombinasi teks dan suara narrator membuat pembelajaran dapat di nikmati menggunakan beberapa indra sekaligus dimana buku tradisional tidak bisa memberikan hal yang sama. Aplikasi ini juga dapat menguji pemahaan daya ingat dengan kuis yang di berikan. 


\section{SARAN}

Adapun aplikasi ini masih dapat di kembangkan dan di teliti terutama dalam beberapa aspek seperti:

a. Jenis-jenis kupu-kupu yang ada bisa diperbanyak.

b. Adanya animasi dalam proses metamorfosis kupu-kupu berupa perubahan dari tiap fase metamorfosis.

c. Dapat di lakukan pengujian pada siswa SMP secara langsung untuk melihat tingkat efektifitas penggunaan Augmented Reality dibanding buku tradisional.

\section{DAFTAR PUSTAKA}

[1] D. A. Landis, "Productive engagement with agriculture essential to monarch butterfly conservation," Environ. Res. Lett., vol. 12, no. 10, p. 101003, 2017.

[2] J. Trappe, F. Kunz, S. Weking, and J. Kamp, "Grassland butterfly communities of the Western Siberian forest steppe in the light of post-Soviet land abandonment," J. Insect Conserv., pp. 1-14, Oct. 2017.

[3]. V. Marín-Díaz, "The Relationships Between Augmented Reality And Inclusive Education In Higher Education". Bordón. Revista de Pedagogía, 69(3), 125-142., vol. 3, https://doi.org/10.13042/Bordon.2017.51123. 2017.

[4] R. T. Azuma, "A survey of augmented reality," Presence Teleoperators Virtual Environ., vol. 6, no. 4, p. 355, Aug. 1997.

[5] Y. P. Edson, A. Wahyudi, and C. Dumingan, "A Proposed Combination of Photogrammetry, Augmented Reality and Virtual Reality Headset for heritage visualisation," in 2016 International Conference on Informatics and Computing (ICIC), Lombok, Indonesia, 2016, vol. 1, pp. 43-48.

[6] A. Wahyudi and O. R Tatangin, Aplikasi Wisata 3D Virtual First Person View(FPV) Pantai Lakban Ratatotok, vol. 6. 2017.

[7] T. Chatzidimitris, D. Gavalas, and D. Michael, "SoundPacman: Audio augmented reality in location-based games," in 2016 18th Mediterranean Electrotechnical Conference (MELECON), 2016, pp. 1-6.

[8] A. Wahyudi, "ARca: Perancangan Buku Interaktif Berbasis Augmented Reality pada Pengenalan dan Pembelajaran Candi Prambanan dengan Smartphone Berbasis Android," J. Nas. Tek. Elektro Dan Teknol. Inf. JNTETI, vol. 3, Feb. 2014.

[9]. Solak, E., \& Cakir, R. (2015). Exploring the Effect of Materials Designed with Augmented Reality on Language Learners' Vocabulary Learning. Journal of Educators Online, 12(2), 50-72.

[10]. Sommerville,I.,2003, Software Engineering, Jilid 1, 6thedition, Erlangga, Jakarta. 